\title{
MODELING THE SPATIAL VARIABILITY OF THE ELECTRICAL CONDUCTIVITY OF THE SOIL USING DIFFERENT SPATIAL INTERPOLATION METHODS: CASE OF THE DAWLING NATIONAL PARK IN MAURITANIA
}

DOI: 10.21163/GT_2018.132.01

\begin{abstract}
Mohamed Mahmoud Ould ABIDINE ${ }^{1,2,3}$, Ahmed El ABOUDI', Aminetou KEBD ${ }^{2}$, Brahim Baba ALOUEIMINE ${ }^{2}$, Youssef DALLAHI , Ahmedou SOULË ${ }^{3}$, Ahmedou $V A D E L^{2}$
\end{abstract}

\begin{abstract}
:
One of the most important indicators for land degradation is the progressive salinization of soils. This work, conducted at the Dawling National Park (southern Mauritania), assess the effects of salinity on soil quality. Analyzes of spatial variation in salinity were performed using interpolation and spatial analysis (GIS) methods. Thus, maps of electrical conductivity have been developed using several methods of interpolation and spatial analysis: Inverse Weighting (IDW), Local Polynomial Interpolation (LPI), Radial Base Function (RBF) and Ordinary Kriging (OK). The obtained results showed that the best estimator is IDW method, which provides a good ability to predict electrical conductivity, with a mean squared error (RMSE) of $0.34 \mathrm{mS} / \mathrm{cm}$ and a correlation coefficient (R) of 0.99 .
\end{abstract}

Key-words: Electrical Conductivity, Salinity, Soil, GIS, Interpolation, Diawling National Park, Mauritania.

\section{INTRODUCTION}

The lower delta of the Senegal River is characterized by the interface between continental and coastal waters. However, these ecosystems are considered the most important in West Africa (Hamerlynck \& Cazottes, 1998). This area is home to many unique wetland ecosystems that have been severely disrupted by the droughts of the 1970s and the construction of the anti-salt dam since the 1980s. In addition to the construction of the Diama anti-salt dam in 1986, a formation of many clay dunes with a high salt concentration was observed (Barbiéro et al., 2004; Barbiéro \& Caruba, 1998; Hamerlynck, 2000; Ngom et al., 2016). The Diawling National Park (PND) located in the lower delta of the Senegal River was created in 1991 to restore the old flood plains and to preserve the ecosystem values and compensate the negative effects of the Diama dam.

\footnotetext{
${ }^{1}$ Université Mohammed V, Faculté des Sciences, 1014 Rabat, Maroc, hmd108@yahoo.fr, elaboudi@gmail.com;

${ }^{2}$ Université de Nouakchott Al Aasriya, Faculté des Sciences et Techniques, 880 Nouakchott, Mauritanie,ahmedou.vadel@yahoo.fr,amikebd@yahoo.fr,ibrahim3933@yahoo.fr;

${ }^{3}$ Ecole Normale Supérieure, Centre de Recherche pour la Valorisation de la Biodiversité, 990 Nouakchott, Mauritania,ahmdous@yahoo.fr;

${ }^{4}$ Université Cadi Ayyad, Ecole Normale Supérieure, B.P2400 Marrakech, Maroc, dallahi.youssef@gmail.com.
} 
In addition, soil salinization present a common problem in the Senegal River delta (Ngom et al., 2016). It affects plant growth, agricultural productivity, soil and water quality, and increases soil erosion, especially in semi-arid and arid regions(Asfaw et al. 2018; Elgettafi et al. 2011; Elhag, 2016; Yao \& Yang, 2010). According to several studies, the phenomenon of salinization can lead to a loss of arable land with soil degradation(Gorji et al. 2017; Seyedmohammadi et al. 2016; Tripathi et al. 2015). The detection, monitoring and mapping of soils affected by salinities have major challenges because of the involvement of certain dynamic processes. Indeed, the spatial variability of electrical conductivity (EC) is an important indicator of soil salinity (Marko et al., 2014; Seyedmohammadi et al., 2016; Tripathi et al., 2015). The interpolation techniques proposed by some geographic information analysis tools are used to model results on a given surface. The accuracy of spatial modeling methods of soil properties has been analyzed in several studies (Saito et al., 2005; Seyedmohammadi et al., 2016; Tripathi et al., 2015; Varouchakis \& Hristopulos, 2013). Geostatistical methods have been used in several studies, to estimate electrical conductivity (Bhunia et al., 2018; Friedel, 2006; Khosravi et al., 2016; Seyedmohammadi et al., 2016; Tripathi et al., 2015; Zehtabian et al., 2012). However, it is appropriate to adopt an effective technique to predict the spatial distribution of certain soil characteristics (Emadi \& Baghernejad, 2014; Seyedmohammadi et al., 2016; Tripathi et al., 2015; Zarco-Perello \& Simões, 2017). The objective of this work is to study the interpolation of the flood basins of the PND in order to evaluate the spatial extent of the zones degraded by soil salinity. Indeed, four interpolation methods will be tested for spatial analysis: IDW, LPI, RBF and OK. In addition, about 100 soil samples were taken from the surface of the PND. A global portable positioning system (GPS) was used to record the coordinates of each sampling point.

\section{MATERIALS AND METHODS}

\subsection{Study zone}

This study was conducted in the Dawling National Park in southwestern Mauritania. This zone is extended between $16^{\circ} 35^{\prime} 00^{\prime \prime} \mathrm{N}, 16^{\circ} 20^{\prime} 00^{\prime \prime} \mathrm{W}$ and $16^{\circ} 05^{\prime} 00 \mathrm{~N}$ and $16^{\circ}$ $30^{\prime} 00^{\prime \prime} \mathrm{W}$. It covers an area of $353 \mathrm{~km}^{2}$. It is a sub-Sahelian zone with low rainfall $(170 \mathrm{~mm}$ / year)(Mohamedou et al., 1998). The park consists of several basins that develop from north to south: Diawling, Bell, Gambar and N'Tiallakh. These basins are surrounded by a coastal dune to the northwest, the dunes Birette and Ziré and the right bank of the Senegal River to the east (Fig. 1). The flora of this area is conditioned by the presence of salt and the nature of the soil. The plant cover is marked by species like Indigofera ablongifolia, Iponea, Acacia nilotica, Sporobulus, Tamarix senegalensis, Rhizophora mangle, Avicennia africana, Acacia radiana, Balanites aegyptiaca, Salvadora persica, Mitragyna inermis, Zizyphus mauritana. However, the fauna is represented by common mammals (jackals, warthogs, wildcats, hares, etc.), reptiles (turtles, python, Nile monitor, crocodile), a large variety of birds that coexist according to the season and the salinity of the waters, crabs and mules typical of the river valley. 


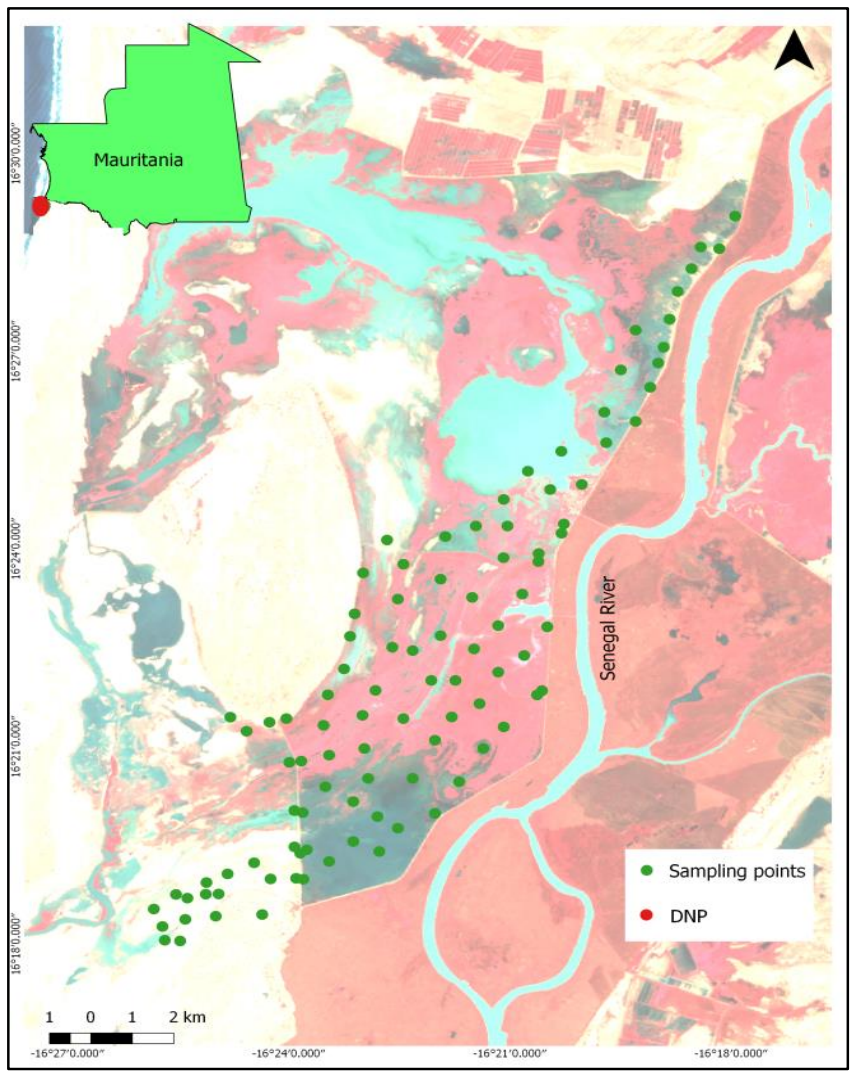

Fig. 1. Study area and soil sampling sites in the study area located in the DNP, Mauritania.

\subsection{Soil sampling and interpolation methods}

A sample of 100 soil electrical conductivity values was taken randomly distributed over the study area (Fig. 1).Samples were taken from the first $20 \mathrm{~cm}$ layer. The coordinates of each sampling point were collected by portable GPS (Garmin 78). The values of the electrical conductivity for each sample were obtained by the diluted extract method(El Oumri \& Vieillefon, 1983; Montoroi, 1997). Statistical processing and spatial analysis of field data were performed using SPSS 20 and ArcGIS 10.3 software.

The results of several spatial analysis methods were compared:

\section{IDW}

Inverse Distance Weighting (IDW) is one of the interpolation methods used in the field of soil science (Bhunia et al., 2018; Robinson \& Metternicht, 2006; Seyedmohammadi et al., 2016). IDW estimates are based on known locations in the vicinity (formula (1)). The weights assigned to the interpolation points are determined by the inverse of the distance from the interpolation point. 


\section{With}

$$
Z\left(x_{0}\right)=\frac{\sum_{i=1}^{n} \frac{x_{i}}{h_{i j}^{\beta}}}{\sum_{i=1}^{n} \frac{1}{h_{i j}^{\beta}}}
$$

$\mathrm{Z}(\mathrm{x} 0)$ is the interpolated value; $\mathrm{n}$ represents the total number of sample points; $\mathrm{x}_{\mathrm{i}}$ is the measured value, $h_{i j}$ is the separation distance between the interpolated value and the measured value; $\beta$ indicates the weighting power $(\beta=2)$.

\section{$\mathrm{OK}$}

The Ordinary Kriging method is one of the interpolation techniques that is also frequently used (Mousavifard et al., 2013; Poshtmasari et al., 2012) . This technique makes it possible to estimate for an area around a sampled point (Pang et al., 2011; Seyedmohammadi et al., 2016; Tripathi et al., 2015). The semivariogram formula is expressed as follows:

$$
\gamma(h)=\frac{1}{2 N(h)} \sum_{i=1}^{N(h)}\left[Z\left(x_{i}\right)-Z\left(x_{i}+h\right)\right]^{2}
$$

With

$\gamma(\mathrm{h})$ is the semivariance; $\mathrm{N}(\mathrm{h})$ is the total number of data pairs separated by a distance; $h$ is the lag distance; $\mathrm{Z}$ represents the measured value for soil properties; and $\mathrm{x}$ is the position of the soil samples.

\section{Radial basis function (RBF)}

This method brings together a series of exact interpolation techniques that involve passing the surface through each evaluated sample value. The RBF function changes according to the distance from a location (Poshtmasari et al., 2012; Seyedmohammadi et al., 2016; Wang et al., 2014). There are five different basic functions: thin-plate spline (TPS), spline with tension (SPT), completely regularized spline (CRS), multi-quadratic function (MQ and inverse multi-quadratic function (IMQ)(Bhunia et al., 2018).

\section{Local polynomial interpolation (LPI)}

LPI corresponds to the local polynomial obtained by using sampling points in a neighborhood. The interpolation is done by the weighting according to the distance (Baram et al., 2014; Hani and Abari, 2011; Seyedmohammadi et al., 2016). LPI is capable of producing surfaces that capture the short range variation (Bhunia et al., 2018; Johnston, 2004). In addition, it fits the local polynomial using points only within the specified neighborhood instead of all the data(Poshtmasari et al., 2012; Wang et al., 2014)

To compare the interpolation methods, in terms of precision and performance, the interpolated values will be extracted for the 100 sampling sites the interpolated values will be extracted from the 100 sampling sites, then compare with the actual values using the cross-validation procedure. Three performance indicators have been used: 
Root Mean Square Error (RMSE): The square root of the arithmetic average of squared deviations between measured and interpolated values (eq. 3).

$$
R M S E=\sqrt{\frac{1}{N} \sum_{i=1}^{n}\left(\mathrm{y}_{i}-y_{i}{ }^{\prime}\right)^{2}}
$$

The mean absolute error (MAE): the arithmetic mean of the absolute values of the differences between the measured values and those interpolated (eq. 4).

$$
M A E=\frac{1}{N} \sum_{i=1}^{n}\left|y_{i}-y_{i}^{\prime}\right|
$$

Correlation coefficient $(\mathrm{R})$ : the standardization of the covariance by the product of the standard deviations of the variables.

$$
R=\sqrt{1-\left[\frac{\left(\sum_{i=1}^{n}\left(y_{i}-y_{i}{ }^{\prime}\right)^{2}\right)}{\left.\sum_{i=1}^{n}\left(y_{i}-\overline{y_{i}}\right)^{2}\right]}\right.}
$$

Where: $y_{i}$ indicates the measured value; $y_{i}{ }^{\prime}$ is the predicted value, $\bar{y}_{i}$ is the average of the measured value, and $\mathrm{n}$ is the total number of observations.

\section{RESULTS AND DISCUSSION}

Table 1 summarizes the descriptive statistics of the experimental data. We note an average value of the order of $11 \mathrm{~ms} / \mathrm{cm}$. However, the measured values show a strong variability in space.

Table 1.

Descriptive statistics of the data used

\begin{tabular}{|c|c|c|c|c|c|c|c|c|}
\hline & Min & Max & average & SD* & CV* & Modal value & Kurtosis & Skewness \\
\hline EC (ms/Cm) & 0,29 & 64,60 & 11,48 & 10,41 & 0,91 & 3,01 & 6,79 & 2,15 \\
\hline
\end{tabular}

*SD: Standard Deviation; *CV: Coefficient of Variation

The PND is a special environment, strongly structured under the influence of the arrival of the fresh waters of the Senegal River and the salty waters of the ocean by the action of the tides. The control of the quantities of fresh water by the Dima dam was at the origin of the salinisation phenomena that affected the distribution of biodiversity in the area. Indeed, the nature of the vegetation in this ecosystem is strongly conditioned by the presence of salt (Duvail, 2001). Thus, the disappearance of a forest of Acacia nilotica which was located on the Birette dune and on the edge of the floodplains was associated with the increase of the salinity(Taïbi et al., 2007). Also, mangrove forests, a sensitive 
habitat, have been reduced under the combination of drought and the dam effect(Duvail, 2001; Taïbi et al., 2007).

As for Acacia nilotica, salinization is associated with the decrease in the surfaces of Sporobolus robustus, Nymphea lotus, plants that support the economic activities of the local population (skin tanning, matting, feeding and medication)(Taibi et al., 2007) . Similarly, fishing has become more difficult in the park today, which has resulted in reduced catches by fishermen and especially south of the park especially in the N'Tiallakh basin (Duvail, 2001; Taïbi et al., 2007). Finally, the waterbirds that frequent the area coexist in the basins of the park according to the salinity of the water(Hamerlynck, 2000).

The evaluation of the prediction capacity of the interpolation methods has been implemented by the calculation of the performance indicators of the modeling (Table 2). Indeed, the methods LPI and OK show weak performances, with an error close to 8 and a correlation which remains lower than 0.7 . RBF and IDW methods give similar results with respect to the correlation coefficient. Nevertheless, the IDW method shows a better quality of prediction of the electrical conductivity of the soil, with an RMSE of 0.34, a MAE of 0.09 and a correlation coefficient of 0.99 (Fig. 3).

Table 2.

\section{Parameters for Evaluating Interpolation Performance}

\begin{tabular}{|c|c|c|c|}
\hline Method & R & RMSE & MAE \\
\hline IDW & 0,99 & 0,34 & 0,09 \\
\hline LPI & 0,65 & 8,16 & 4,90 \\
\hline OK & 0,59 & 8,73 & 5,40 \\
\hline RBF & 0,98 & 1,08 & 0,41 \\
\hline
\end{tabular}

The different interpolation methods were used to develop maps of the spatial variation in electrical conductivity (Fig. 2). Areas south and north of the park are characterized by high electrical conductivity compared to other park territories. These areas correspond to the two basins of N'Tiallakh and DiawlingTichilitt. It is noted that the appearance of some points, low conductivity, scattered in these areas, this can be related to the structure of the soil. According to (Duvail, 2001), the salinity phenomena in these basins are greater in magnitude and intensity than in the other basins of the park. This is explained by the effects of the floods. The salty waters from the Atlantic Ocean are responsible for the salinity of the N'Tiallakh basin which is located southwest of the PND and communicates directly with the sea by the N'tiallakh's swamp. Indeed, the electrical conductivity seems to have risen after the closure of the Diama dam. Hamerlynck (1998) postulates that the salinity of the water in these areas fluctuates greatly during the dry season, scenario that was not considered in the development of the park management plan. Other research has shown that the salinity of well water, even those near the riverbed, has been steadily increasing (Davranche \& Taïbi, 2015; Taïbi et al., 2007). Also the Diawling Tichilitt basin, located in the North, is flooded by the salt water from the N'Tiallakh basin by Lekser's work. Low salinity is recorded in the center of the study area (Bell Basin). This is explained by the 
proximity of the structure allowing the fresh water of the Senegal River to flood this basin during certain months of the year.
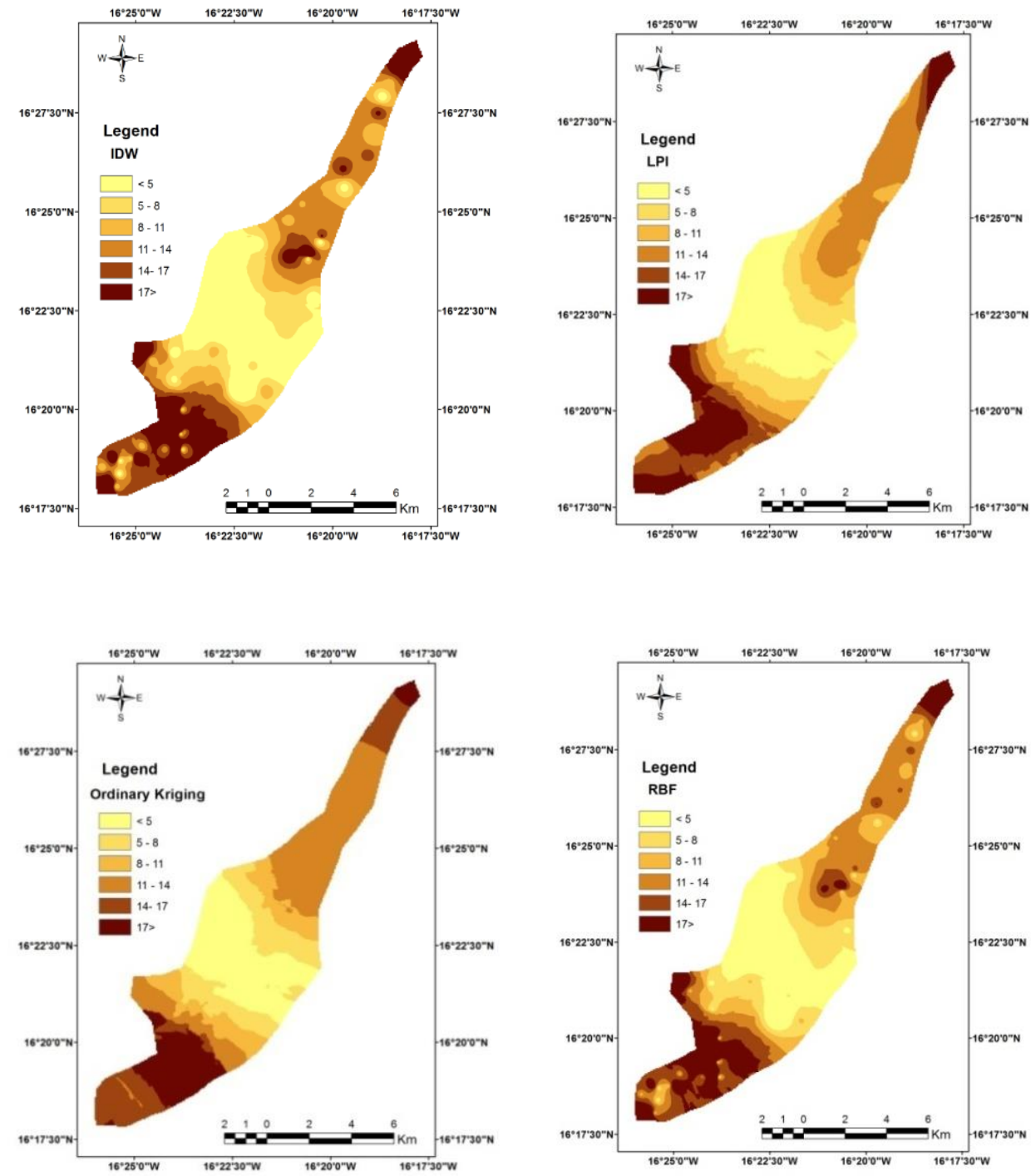

Fig. 2. Spatial distribution map of soil EC $(\mathrm{mS} / \mathrm{cm})$ by different methods.

Comparing the results obtained by this work with those found by other studies, we can cite (Emadi \& Baghernejad, 2014; Karydas et al., 2009; Poshtmasari et al., 2012) who highlighted that the IDW method gives a good prediction of electrical conductivity, with an average error of $0.38 \mathrm{mS} / \mathrm{cm}$. However,Tripathi et al.(2015) selected the OK method as the best interpolation technique for soil salinity, with an average error of about 1.6. The choice 
of the OK method was justified by Mohammad et al., 2010 who studied spatial distribution of soil properties by applying interpolation techniques such as IDW and OK.
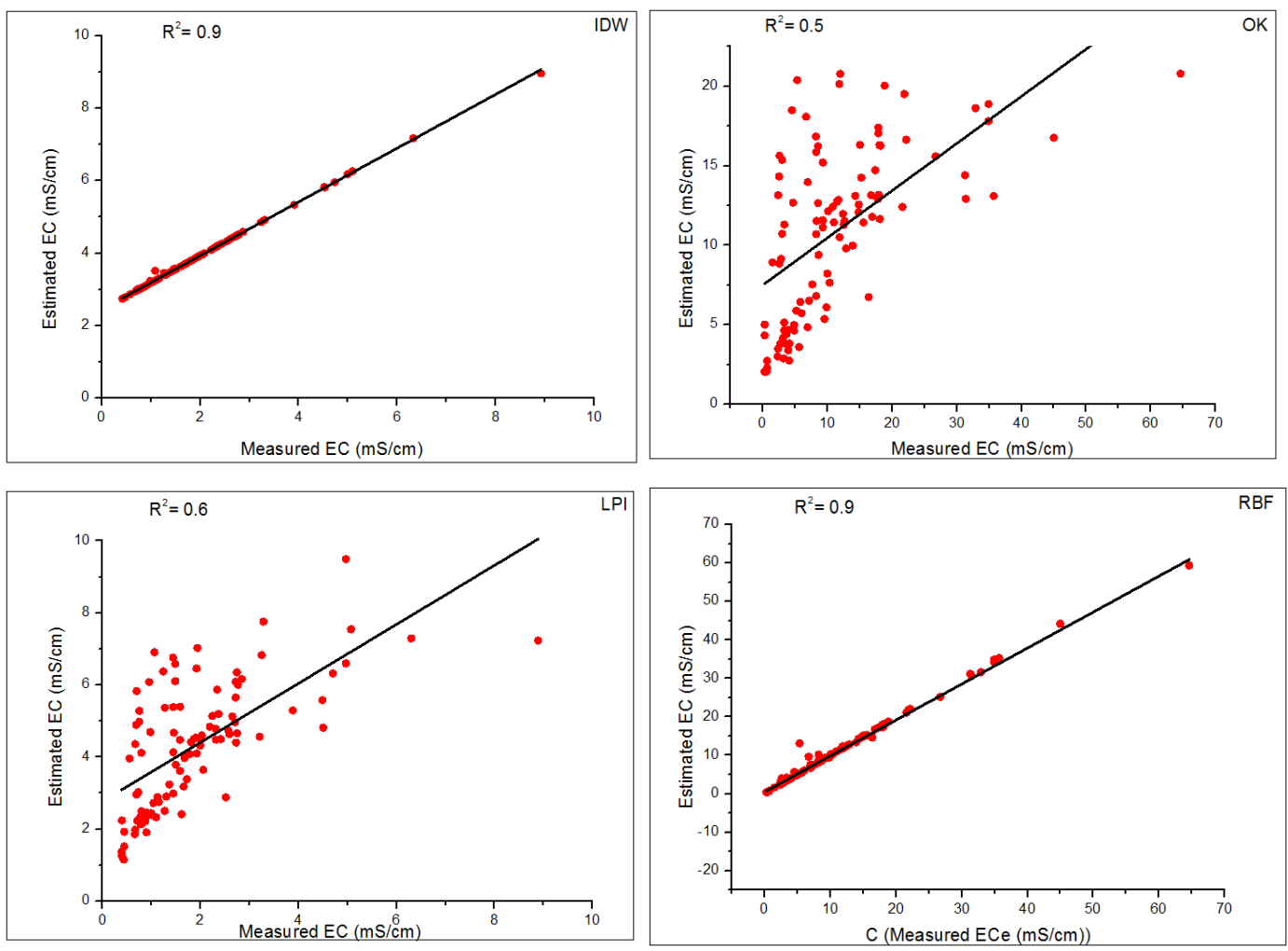

Fig. 3. Cloud of points representing the values measured according to the values predicted by different methods.

\section{CONCLUSION}

In this work, we studied the spatial variation of salinity at the Dawling National Park. The evaluation took place on 100 points, using different interpolation techniques. The results obtained showed a high variability of electrical conductivity from one point to another within the study area. The average value is about $11 \mathrm{~ms} / \mathrm{cm}$. The highest salinity level has been recorded in areas south and north of the PND. Low EC values were observed in the center of the study area. These fluctuations have been attributedto the processes of floods, and upstream links with the fresh waters of the river and downstream with those of the sea. The calculation of the estimation performance indicators made it possible to select the IDW method as the best interpolation technique adapted to our study area. The mean squared error is in order of 0.34 and the correlation coefficient approximates a value of 0.99 . 


\section{REFERENCES}

Mohamedou, A. O., Aventurier, A., Barbiero, L., Caruba, R. \& Valles, V. (1998) Geochemistry of Clay Dunes and Associated Pan in the Senegal Delta, Mauritania. Geochem. Clay Dunes, 265-280.

Asfaw, E., Suryabhagavan, K.V. \& Argaw, M. (2018) Soil salinity modeling and mapping using remote sensing and GIS: The case of Wonji sugar cane irrigation farm, Ethiopia. J. Saudi Soc. Agric. Sci. 17, 250-258. https://doi.org/10.1016/j.jssas.2016.05.003.

Baram, S., Kurtzman, D., Ronen, Z., Peeters, A. \& Dahan, O. (2014) Assessing the impact of dairy waste lagoons on groundwater quality using a spatial analysis of vadose zone and groundwater information in a coastal phreatic aquifer. J. Environ. Manage., 132, 135-144. https://doi.org/10.1016/j.jenvman.2013.11.008.

Barbiéro, L. \& Caruba, R. (1998) Influence de la maturation des sols de mangrove sur la déflation éolienne et la formation des dunes argileuses dans le delta du fleuve Sénégal. Comptes Rendus-Acad. Sci. Paris Ser. 2 Sci. Terre Planetes Fasc. A, 327, 115-120.

Barbiéro, L., Mohamedou, A. O., Laperrousaz, C., Furian, S. \& Cunnac, S. (2004) Polyphasic origin of salinity in the Senegal delta and middle valley. Catena, 58, 101-124.

Bhunia, G. S., Shit, P. K. \& Maiti, R. (2018) Comparison of GIS-based interpolation methods for spatial distribution of soil organic carbon (SOC). J. Saudi Soc. Agric. Sci., 17, 114-126. https://doi.org/10.1016/j.jssas.2016.02.001.

Davranche, A. \& Taïbi, A. N. (2015) Les changements d'occupation et d'usage du sol, des processus multidimensionnels complexes qui affectent la biodiversité. L'Harmattan. 2015, 978-2-343-06972-2.

Duvail, S. (2001) Scenarios hydrologiques et modeles de developpement en aval d'un Grand Barrage: Les usages de l'eau et le partage des ressources dans le delta mauritanien du fleuve Sénégal. Université Louis Pasteur (Strasbourg I).

El Oumri, M. \& Vieillefon, J. (1983) Etude Expérimentale d la Conductivité Electrique Globale des Sols. Appl. À L’Estimation Leur Salin. Cah ORSTOM Sér Pédol, 10, 91-108.

Elgettafi, M., Himi, M., Casas, A. \& Elmandour, A. (2011) Hydrochemistry caracterisation of groundwater salinity in kert aquifer, ne Morocco. Geogr. Tech. 14 (2), 15-22.

Elhag, M. (2016) Evaluation of Different Soil Salinity Mapping Using Remote Sensing Techniques in Arid Ecosystems. Saudi Arabia. J. Sens. 1-8. https://doi.org/10.1155/2016/7596175.

Emadi, M. \& Baghernejad, M. (2014) Comparison of spatial interpolation techniques for mapping soil pH and salinity in agricultural coastal areas, northern Iran. Arch. Agron. Soil Sci. 60, 1315-1327. https://doi.org/10.1080/03650340.2014.880837.

Friedel, M. J. (2006) Reliability in estimating urban groundwater recharge through the Vadose Zone, in: Urban Groundwater Management and Sustainability. Springer, pp. 169-182.

Gorji, T., Sertel, E. \& Tanik, A. (2017) Monitoring soil salinity via remote sensing technology under data scarce conditions: A case study from Turkey. Ecol. Indic. 74, 384-391. https://doi.org/10.1016/j.ecolind.2016.11.043.

Hamerlynck, O. (2000). Restauration du Parc National du Diawling (Mauritanie). In: Groupe d'experts des plaines d'inondation sahéliennes. Vers une gestion durable des plaines d'inondation sahéliennes. UICN, Gland, Suisse et Cambridge, Royaume-Uni. p. 214.

Hamerlynck, O. \& Cazottes, F. (1998) Le parc national du diawling (mauritanie) : infrastructures hydrauliques pour la restauration dune plaine d'inondation et la création d'un estuaire artificiel. Sud Sci. Technol, 28-38.

Hani, A. \& Abari, S. A. H. (2011) Determination of Cd, Zn, K, pH, TNV, Organic Material and Electrical Conductivity (EC) Distribution in Agricultural Soils using Geostatistics and GIS 
(Case Study: South-Western of Natanz-Iran). World Acad. Sci. Eng. Technol. Int. J. Biol. Biomol. Agric. Food Biotechnol. Eng. 5, 852-855.

Johnston, K. (2004) ArcGIS 9: using ArcGIS geostatistical analyst. Esri Press.

Karydas, C. G., Gitas, I. Z., Koutsogiannaki, E., Lydakis-Simantiris, N. \& Silleos, G. N. (2009) Evaluation of spatial interpolation techniques for mapping agricultural topsoil properties in Crete. EARSeL EProceedings, 8, 26-39.

Khosravi, H., Karimi, K. \& Mesbahzadeh, T. (2016) Investigation of spatial structure of groundwater quality using geostatistical approach in Mehran Plain, Iran. Pollution, 2, 5765.

Marko, K., Al-Amri, N. S. \& Elfeki, A. M. M. (2014) Geostatistical analysis using GIS for mapping groundwater quality: case study in the recharge area of Wadi Usfan, western Saudi Arabia. Arab. J. Geosci. 7, 5239-5252. https://doi.org/10.1007/s12517-013-1156-2.

Mohammad, Z.-M., Taghizadeh-Mehrjardi, R. \& Akbarzadeh, A. (2010) Evaluation of geostatistical techniques for mapping spatial distribution of soil $\mathrm{pH}$, salinity and plant cover affected by environmental factors in Southern Iran. Not. Sci. Biol,. 2, 92-103.

Montoroi, J. P. (1997) Conductivité électrique de la solution du sol et d'extraits aqueux de sol Application à un sol sulfaté acide salé de Basse-Casamance (Sénégal). Étude Gest. Sols, 4, 279-298.

Mousavifard, S. M., Momtaz, H., Sepehr, E., Davatgar, N. \& Sadaghiani, M. H. R. (2013) Determining and mapping some soil physico-chemical properties using geostatistical and GIS techniques in the Naqade region, Iran. Arch. Agron. Soil Sci. 59, 1573-1589. https://doi.org/10.1080/03650340.2012.740556.

Ngom, F. D., Tweed, S., Bader, J.-C., Saos, J.-L., Malou, R., Leduc, C. \& Leblanc, M. (2016) Rapid evolution of water resources in the Senegal delta. Glob. Planet. Change, 144, 34-47. https://doi.org/10.1016/j.gloplacha.2016.07.002.

Pang, S., Li, T.-X., Zhang, X.-F., Wang, Y.-D. \& Yu, H.-Y. (2011) Spatial variability of cropland lead and its influencing factors: A case study in Shuangliu county, Sichuan province. China. Geoderma, 162, 223-230. https://doi.org/10.1016/j.geoderma.2011.01.002

Poshtmasari, H. K., Sarvestani, Z. T., Kamkar, B., Shataei, S. \& Sadeghi, S. (2012) Comparison of interpolation methods for estimating $\mathrm{pH}$ and $\mathrm{EC}$ in agricultural fields of Golestan province (north of Iran). Int. J. Agric. Crop Sci., 4, 157-167.

Robinson, T. P. \& Metternicht, G. (2006) Testing the performance of spatial interpolation techniques for mapping soil properties. Comput. Electron. Agric., 50, 97-108. https://doi.org/10.1016/j.compag.2005.07.003.

Saito, H., McKenna, S. A., Zimmerman, D. A. \& Coburn, T. C. (2005) Geostatistical interpolation of object counts collected from multiple strip transects: Ordinary kriging versus finite domain kriging. Stoch. Environ. Res. Risk Assess., 19, 71-85. https://doi.org/10.1007/s00477-004-0207-3.

Seyedmohammadi, J., Esmaeelnejad, L. \& Shabanpour, M. (2016) Spatial variation modelling of groundwater electrical conductivity using geostatistics and GIS. Model. Earth Syst. Environ. 2, 1-10. https://doi.org/10.1007/s40808-016-0226-3.

Taïbi, A. N., Barry, M. el H., Jolivel, M., Ballouche, A., Baba, M. L. O. \& Moguedet, G. (2007) Enjeux et impacts des barrages de Diama (Mauritanie) et Arzal (France) : des contextes socio-économiques et environnementaux différents pour de mêmes conséquences. Norois, 51-66. https://doi.org/10.4000/norois.1536.

Tripathi, R., Nayak, A. K., Shahid, M., Raja, R., Panda, B. B., Mohanty, S., Kumar, A., Lal, B., Gautam, P. \& Sahoo, R. N. (2015) Characterizing spatial variability of soil properties in salt affected coastal India using geostatistics and kriging. Arab. J. Geosci. 8, 10693-10703. https://doi.org/10.1007/s12517-015-2003-4. 
Varouchakis, A. \& Hristopulos, D. T. (2013) Comparison of stochastic and deterministic methods for mapping groundwater level spatial variability in sparsely monitored basins. Environ. Monit. Assess., 185, 1-19. https://doi.org/10.1007/s10661-012-2527-y.

Wang, S., Huang, G. H., Lin, Q. G., Li, Z., Zhang, H. \& Fan, Y. R. (2014) Comparison of interpolation methods for estimating spatial distribution of precipitation in Ontario, Canada: Comparison of interpolation methods for precipitation distribution. Int. J. Climatol., 34, 3745-3751. https://doi.org/10.1002/joc.3941.

Yao, R. \& Yang, J. (2010) Quantitative evaluation of soil salinity and its spatial distribution using electromagnetic induction method. Agric. Water Manag., 97, 1961-1970. https://doi.org/10.1016/j.agwat.2010.02.001.

Zarco-Perello, S. \& Simões, N. (2017) Ordinary kriging vs inverse distance weighting: spatial interpolation of the sessile community of Madagascar reef, Gulf of Mexico. PeerJ, 5, e4078. https://doi.org/10.7717/peerj.4078.

Zehtabian, G. R., Mohammad Asgari, H. \& Tahmoures, M. (2012) Assessment of spatial structure of groundwater quality variables based on the geostatistical simulation. Desert, 17, $215-224$. 